\title{
Identification of Best Parents based on per se Performance and gca Effects for Yield and Water use Efficiency Related Traits in Mungbean
}

B. Rupesh Kumar Reddy ${ }^{1}$, K. Hariprasad Reddy',

D. Mohan Reddy'2, P. Sudhakar ${ }^{2}$, B. Ravindra Reddy ${ }^{1}$

10.18805/IJARe.A-5835

\begin{abstract}
Background: Among the constraints for low yield of mungbean, drought stress and heat stress are prominent. Water deficits and high temperature occur together in many environments and both stresses can interact to reduce yields. Thus, combination of water use efficiency and high temperature tolerance traits are relevant rather than a single trait used as selection criteria for screening appropriate plant ideotype. The present study is contemplated to identify superior parents for yield, yield attributes, water use efficiency and thermo tolerance related traits through combining ability analysis.

Methods: Twenty one $F_{1}$ crosses were generated by crossing seven diverse mungbean genotypes viz., ML 267, LGG 528, MGG 390, WGG 42, AKM 9904, LM 95 and EC 362096 in a $7 \times 7$ diallel fashion without reciprocals. Further, $21 \mathrm{~F}_{1}$ crosses along with seven parents were evaluated to study the the mean performance of the seven parents and their $21 F_{1}$ crosses and combining ability of the parents and crosses and gene action for yield, yield components and water use efficiency related traits.

Result: The present investigations confirmed that some of the parents with significant positive gca effects for seed yield per plant and showed significant positive gca effects for one or more yield, WUE and heat stress tolerance contributing traits. Combination of mean performance and gca effects would result in the selection of potential parents with good reservoir of superior genes. The parents which exhibited high per se performance also displayed good general combining ability effects. Hence, per se performance may be used effectively for the selection of parents. In the present study, MGG 390, ML 267 and EC 362096 were adjudged as the best parents based on both mean and gca effects.
\end{abstract}

Key words: Combining ability, Heat stress tolerance, Mungbean, Water use efficiency, Yield attributes.

\section{INTRODUCTION}

Mungbean popularly known as green gram [Vigna radiata (L.) Wilczek] occupies predominant position in the pulse basket in terms of dietary elements and agronomic aspects. Genetic enhancement for yield and quality seed would be a critical factor in productivity. Among the constraints for low yields of mungbean, drought stress and heat stress are prominent. Water deficits and high temperature occur together in many environments and both stresses can interact to reduce yields. Improving the tolerance of crops to drought requires a broader interdisciplinary approach for understanding factors determining yield and identification of reliable physiological traits. Plant scientists are making concerted efforts in identifying genotypes with high yield coupled with relatively better drought tolerance. Combination of different water use efficiency and high temperature tolerance traits are relevant, rather than a single trait used as selection criteria for screening appropriate plan.

More rapid progress may be achieved by a prior knowledge of the physiological basis of surrogate traits related to WUE, such as specific leaf area (SLA), soil and plant analytical development chlorophyll meter reading (SCMR) and specific leaf weight (SLW). SLA is negatively correlated with WUE whereas SCMR is positively associated with WUE. Hence, these traits could be used for selecting
${ }^{1}$ Sri Venkateswara Agricultural College, Tirupati-517 502, Andhra Pradesh, India.

${ }^{2}$ Regional Agricultural Research Station, Tirupati-517 502, Andhra Pradesh, India.

Corresponding Author: B. Rupesh Kumar Reddy, Sri Venkateswara Agricultural College, Tirupati-517 502, Andhra Pradesh, India. Email: rupeshkumarreddyb@gmail.com

How to cite this article: Reddy, B.R.K., Reddy, K.H., Reddy, D.M., Sudhakar, P., Reddy, B.R. (2021). Identification of Best Parents based on per se Performance and gca Effects for Yield and Water use Efficiency Related Traits in Mungbean, Indian Journal of Agricultural Research. DOI: 10.18805/IJARe.A-5835.

Submitted: 01-06-2021 Accepted: 21-08-2021 Online: 17-09-2021

higher water use efficient green gram genotypes. Heat tolerance is determined by measuring relative injury percentage. Cell membrane integrity is tested by exposing leaves to high temperature and computing relative injury to the membranes in terms of electrolytes leakage. Lower leakage indicates lower the injury and higher the thermo tolerance. Genetic enhancement for drought and heat stress tolerance could be justifiable through clear understanding of the performance of diverse mungbean genotypes for yield, 
yield contributing, water use efficiency and heat stress tolerance related traits.

General combining ability ( $g c a)$ is an effective tool used in selection of parents based on performance of their progenies. The general combining ability effects of parents for various traits were estimated and accordingly parents were classified as good $(G)$ and poor $(P)$ general combiners and are used in further hybridization and breeding programmes (Arunachalam and Bandyopadhyay, 1979). The parents with significant gca effects in desired direction (positive or negative) were considered as good (G) general combiners and rest of them were regarded as poor $(P)$ general combiners.

The concept of combining ability analysis helps in selection of superior parents when considered along with the mean performances. It also reveals about the nature of gene action involved and thus helps in framing a suitable breeding scheme for the amelioration of the characters under consideration. The estimates of combining ability along with per se performance of genotypes in a crop improvement program have a direct bearing upon the choice of breeding methodology to be followed and to identify the parents and crosses (Khattak et al., 2004) which could be exploited for future breeding programme.

\section{MATERIALS AND MeTHODS}

The present experiment was carried out at dry land farm of Sri Venkateswara Agricultural College, Tirupati, situated at an altitude of $182.9 \mathrm{~m}$. above mean sea level, $32.27^{\circ} \mathrm{N}$ latitude and $79.36^{\circ} \mathrm{E}$ longitude, situated geographically in Southern Agro climatic Zone of Andhra Pradesh, India. The soil is sandy loam with medium fertility. Seven parents viz., ML267, LGG-528, MGG-390, WGG-42, AKM-9904, LM-95 and EC-362096 were raised in paired row method for effecting crosses in a diallel fashion without reciprocals to generate seed of $21 \mathrm{~F}_{1}$ crosses. The $21 \mathrm{~F}_{1}$ crosses along with their seven parents constituted 28 treatments for this experiment.

The seven parents and their $21 \mathrm{~F}_{1}$ crosses were sown in randomized block design with two replications during the first fortnight of November, 2016 at dry land farm, S.V. Agricultural College, Tirupati. Each genotype was sown by dibbling the seeds in two rows of $3 \mathrm{~m}$ length, with a spacing of $30 \mathrm{~cm}$ between the rows and $10 \mathrm{~cm}$ between the plants. All the 28 treatments were allotted at random to the experimental plots in each replication. The crop was fertilized at the rate of $20 \mathrm{~kg} \mathrm{~N}$ and $40 \mathrm{~kg} \mathrm{P}_{2} \mathrm{O}_{5}$ in the form of urea and single super phosphate at the time of sowing. Thinning was done to leave single seedling per hill after 15 days of sowing. Irrigation, weeding and plant protection measures were taken up as and when needed during the crop growth period, apart from practicing standard recommended package of practices to raise a good and healthy crop. Observations were recorded on five randomly chosen competitive plants from each genotype in each replication for the characters viz., plant height, number of branches per plant, number of clusters per plant, pods per cluster, pods per plant, seed yield per plant, 100-seed weight, harvest index, SLA, SCMR, SLW and relative injury. Days to $50 \%$ flowering and days to maturity were recorded on plot basis. The combining ability analysis was carried out according to Model I and Method II of Griffing (1956). The fixed effect model (Model I) was considered to be more appropriate in the present investigation, since the study was restricted to the parents and direct crosses only.

\section{RESULTS AND DISCUSSION}

The estimates of combining ability along with per se performance of genotypes in a crop improvement program have a direct bearing upon the choice of breeding methodology to be followed and to identify the parents and

Table 1: Best parents identified based on per se performance and gca effects for yield and water use efficiency traits in mungbean.

\begin{tabular}{|c|c|c|c|}
\hline \multirow[b]{2}{*}{ Characters } & \multicolumn{3}{|c|}{ Best parents based on } \\
\hline & per se performance & gca effects & $\begin{array}{l}\text { per se performance } \\
\text { and gca effects }\end{array}$ \\
\hline Days to $50 \%$ flowering & ML 267, LGG 528 & WGG 42, LM 95 & - \\
\hline Days to maturity & ML 267, LGG 528 & ML 267, WGG 42 & ML 267 \\
\hline Plant height $(\mathrm{cm})$ & EC 362096, ML 267 & EC 362096, ML 267 & EC 362096, ML 267 \\
\hline Number of branches per plant & ML 267, MGG 390 & ML 267 & ML 267 \\
\hline Number of clusters per plant & MGG 390, WGG 42, LM 95 & MGG 390, ML 267, LGG 528 & MGG 390 \\
\hline Number of pods per cluster & AKM 9904, LGG 528, MGG 390 & MGG 390 & MGG 390 \\
\hline Number of pods per plant & MGG 390, LM 95, AKM 9904 & ML 267, MGG 390, LM 95 & MGG 390, LM 95 \\
\hline 100-seed weight $(\mathrm{g})$ & EC 362096, WGG 42 & EC 362096, WGG 42 & EC 362096, WGG 42 \\
\hline Harvest index (\%) & AKM 9904, MGG 390 & LM 95, ML 267 & - \\
\hline SPAD chlorophyll meter reading & MGG 390, EC 362096, AKM 9904 & LM 95, MGG 390, ML 267 & MGG 390 \\
\hline Specific leaf area $\left(\mathrm{cm}^{2} \mathrm{~g}^{-1}\right)$ & EC 362096, LGG 528 & EC 362096, LGG 528 & EC 362096, LGG 528 \\
\hline Specific leaf weight $\left(\mathrm{g} \mathrm{cm}^{-2}\right)$ & LGG 528, ML 267 & EC 362096, WGG 42 & - \\
\hline Relative injury (\%) & EC 362096, LGG 528 & EC 362096, LGG 528 & EC 362096, LGG 528 \\
\hline Seed yield per plant (g) & ML 267, MGG 390 & EC 362096, ML 267 & ML 267 \\
\hline
\end{tabular}


Table 3: Estimates of general combining ability ( $g c a)$ effects of seven parents for yield, yield attributes and water use efficiency related traits in mungbean.

\begin{tabular}{|c|c|c|c|c|c|c|c|}
\hline Parents & $\begin{array}{l}\text { Days to } 50 \% \\
\text { flowering }\end{array}$ & $\begin{array}{l}\text { Days to } \\
\text { maturity }\end{array}$ & $\begin{array}{l}\text { Plant height } \\
(\mathrm{cm})\end{array}$ & $\begin{array}{c}\text { No. of branches } \\
\text { per plant }\end{array}$ & $\begin{array}{c}\text { No. of clusters } \\
\text { per plant }\end{array}$ & $\begin{array}{l}\text { No. of pods } \\
\text { per cluster }\end{array}$ & $\begin{array}{c}\text { No. of pods } \\
\text { per plant }\end{array}$ \\
\hline ML 267 & 0.05 & $-1.04^{* *}$ & $1.14^{* *}$ & $0.41^{* *}$ & $0.41^{* *}$ & 0.15 & $2.93^{* *}$ \\
\hline LGG 528 & 0.05 & 0.24 & $-0.89^{\star *}$ & -0.03 & $0.29^{*}$ & 0.04 & 1.07 \\
\hline MGG 390 & 0.05 & -0.32 & 0.22 & 0.01 & $0.42^{* *}$ & 0.16 & $2.62^{* *}$ \\
\hline WGG 42 & -0.40 & -0.37 & $-3.13^{* *}$ & $-0.16^{*}$ & $-0.64^{\star *}$ & $-0.32^{* *}$ & $-4.56^{* *}$ \\
\hline AKM 9904 & 0.38 & $0.79^{* *}$ & 0.36 & $-0.24^{* *}$ & $-0.39^{* *}$ & -0.09 & $-2.93^{* *}$ \\
\hline LM 95 & -0.12 & $0.74^{* *}$ & 0.37 & 0.10 & 0.18 & 0.06 & $1.27^{*}$ \\
\hline EC 362096 & -0.01 & -0.04 & $1.94^{* *}$ & -0.09 & $-0.27^{*}$ & 0.01 & -0.94 \\
\hline S.E (gi) & 0.24 & 0.22 & 0.29 & 0.07 & 0.11 & 0.10 & 0.55 \\
\hline Parents & $\begin{array}{l}100 \text {-seed } \\
\text { weight }(\mathrm{g})\end{array}$ & $\begin{array}{c}\text { Harvest } \\
\text { index (\%) }\end{array}$ & $\begin{array}{l}\text { SPAD chlorophyll } \\
\text { meter reading }\end{array}$ & $\begin{array}{l}\text { Specific leaf } \\
\text { area }\left(\mathrm{cm}^{2} \mathrm{~g}^{-1}\right)\end{array}$ & $\begin{array}{c}\text { Specific leaf } \\
\text { weight }\left(\mathrm{gcm}^{-2}\right)\end{array}$ & $\begin{array}{l}\text { Relative } \\
\text { injury (\%) }\end{array}$ & $\begin{array}{l}\text { Seed yield } \\
\text { per plant }(\mathrm{g})\end{array}$ \\
\hline$\overline{M L} 267$ & -0.12 & 0.70 & 0.25 & $6.00^{* *}$ & $0.001^{* *}$ & $-2.14^{* *}$ & $0.41^{*}$ \\
\hline LGG 528 & $-0.23^{* *}$ & -0.12 & -0.12 & $-3.42^{* *}$ & $0.001^{* *}$ & 0.20 & -0.04 \\
\hline MGG 390 & $-0.18^{*}$ & 0.25 & $-0.93^{*}$ & $-2.64^{*}$ & 0.000 & -0.62 & $0.53^{* *}$ \\
\hline WGG 42 & $0.27^{* *}$ & -1.31 & 0.55 & $3.34^{* *}$ & $0.001^{* *}$ & $2.69^{* *}$ & $-1.07^{\star *}$ \\
\hline AKM 9904 & -0.01 & 0.31 & -0.40 & $7.23^{* *}$ & $0.001^{* *}$ & $2.27^{* *}$ & $-0.52^{* *}$ \\
\hline LM 95 & $-0.16^{*}$ & 0.75 & -0.03 & $5.64^{* *}$ & $0.001^{* *}$ & 0.54 & $0.55^{* *}$ \\
\hline EC 362096 & $0.42^{* *}$ & -0.57 & 0.62 & $-16.15^{\star *}$ & $0.001^{* *}$ & $-2.93^{\star *}$ & 0.13 \\
\hline S.E (gi) & 0.07 & 0.65 & 0.41 & 1.10 & 0.00003 & 0.37 & 0.17 \\
\hline
\end{tabular}

${ }^{*}$ Significant at $5 \%$ level, ${ }^{*}$ Significant at $1 \%$ level.

crosses (Khattak et al., 2004) which could be exploited for future breeding programme. Evaluation of parents based on mean performance and gca effects separately might lead to contradiction in selection of promising parents since mean performance of parents was not always associated with high gca effects. Combination of mean performance and gca effects would result in the selection of potential parents with good reservoir of superior genes (Singh and Harisingh, 1985).

Best parents identified based on per se performance and gca effects for yield, yield components and water use efficiency related traits was presented in the Table 1. The mean performance and gca effects of all the genotypes for yield, yield attributes and water use efficiency related traits were presented in the Table 2 and 3 . Among the parents MGG 390, ML 267, LGG 528 and EC 362096 were adjudged as the best parents based on high per se values for more number of traits. Based on gca effects ML 267, EC 362096 and MGG 390 were adjudged as the best parents for majority of the traits.

In the present study, MGG 390, ML 267 and EC 362096 were adjudged as the best parents based on both mean and gca effects. The parent MGG 390 was good for four traits viz., number of clusters per plant, number of pods per cluster, number of pods per plant and seed yield per plant whereas ML 267 was good for four different traits viz., days to maturity, plant height, number of branches per plant and relative injury. The next best parent was EC 362096 which exhibited good mean performance and gca effects for four traits viz., plant height, number of branches per plant, specific leaf area and specific leaf weight (Table 1).
Singh and Harisingh (1985) and Tiwari et al. (1993) had also suggested that parents with high gca effects could produce transgressive segregants in $F_{2}$ or later generations. Thus it was evident that the inclusion of MGG 390, ML 267 and EC 362096 as parents in crossing programme would result in the desirable segregants for high yield coupled with drought and heat stress tolerance in advanced generations.

The present investigation also confirmed that some of the parents with significant positive gca effects for seed yield per plant also showed significant positive gca effects for one or more yield, WUE and heat stress tolerance contributing traits. The parents which exhibited high per se performance also displayed good general combining ability effects. Hence, per se performance may be used effectively for the selection of parents. Similar results of positive association of per se performance and general combining ability and its usefulness in selection of the parents was also reported by Vijaykumar et al. (2017).

\section{CONCLUSION}

From the above discussion, it is concluded that the parents MGG 390, ML 267 and EC 362096 were adjudged as the best parents based on both mean and gca effects. Crosses involving these parents may throw desirable segregants for both yield attributing and WUE and heat stress tolerance related characters. Selection from the segregating generations of the crosses involving the above parents would be effective for genetic enhancement of yield, water use efficiency and heat tolerance. 


\section{REFERENCES}

Arunachalam, V. and Bandyopadhyay, A. (1979). Are multiple crossmultiple pollen hybrids an answer for productive population in Brassica campestris var. brown sarson? Theoretical Applied Genetics. 54: 203-237.

Griffing, B. (1956). Concept of general and specific combining ability in relation to diallel crossing systems. Australian Journal of Biological Sciences. 9: 463-93.

Khattak, G.S.S., Ashrafi, M. and Khan, M.S. (2004). Assessment of genetic variation for yield and yield components in mungbean [Vigna radiata (L.) Wilczek] using generation means analysis. Pakistan Journal of Botany. 36(3): 583-588.
Singh, N.B. and Harisingh (1985). Heterosis and combining ability for kernel size in Rice. Indian Journal of Genetics and Plant Breeding. 45(2): 181-185.

Tiwari, D.S., Vijaipal Singh and Shukla, P.S. (1993). Combining ability studies in mungbean [Vigna radiata (L.) Wilczek] Indian Journal of Genetics and Plant Breeding. 53(4): 395-398.

Vijaykumar, G., Vanaja, M., Babu Abraham, Premkumar, Jyothi Lakshmi, N., Sarkar, B. (2017). Heterosis and combining ability studies in blackgram [Vigna mungo (L.) Hepper] under alfisols of SAT region, India. Electronic Journal of Plant Breeding. 8(2): 541-547. 